\title{
Response of Native White Beans, Phaseolus vulgaris, to Various N Levels in an Oxisol ${ }^{1,2}$
}

\author{
M. A. Lugo-López, J. Badillo-Feliciano, and L. Calduch ${ }^{3}$
}

\begin{abstract}
As field beans (Phaseolus vulgaris) are low $\mathrm{N}$ fixers, $\mathrm{N}$ fertilizers are generally recommended. A study was conducted on a Coto soil, Tropeptic Haplorthox, to ascertain $\mathrm{N}$ demands of a high yielding selection of native white beans. Six levels of $N$ were studied: $0,20,40,80,160$, and $320 \mathrm{~kg} / \mathrm{ha}$ on Bonita, a variety consumers prefer. The Capo fertilizer-yield equation, useful in predicting dry bean yields in terms of the fertilizer $N$ used, was applied to the mean yield data. Not more than $180 \mathrm{~kg} / \mathrm{ha}$ of $\mathrm{N}$ fertilizer are required to complement native soil $\mathrm{N}$ to obtain maximum dry bean yield, indicated by the finding that with $80 \mathrm{~kg} / \mathrm{ha}$ of $\mathrm{N}, 96.7 \%$ of the maximum yield was obtained.

Significant differences were evident in some of the yield components: weight of 10 plants, and number of pods and weight of pods/10 plants were significantly higher in the $160 \mathrm{~kg} / \mathrm{ha} \mathrm{N}$ levels than in the no- and $40 \mathrm{~kg} / \mathrm{ha}$ levels. Number of seeds/pod was significantly lower in the no- $\mathrm{N}$ as compared to the $80-\mathrm{N}$ level. No significant differences were found in plant canopy diameter, but plants from the $160 \mathrm{~kg} / \mathrm{h}$ a treatment were taller than those from the no- and $20-\mathrm{kg} / \mathrm{ha} \mathrm{N}$ levels.
\end{abstract}

\section{INTRODUCTION}

Field beans are considered to be low $\mathrm{N}$ fixers. Levels of nodulation are low and variable (7). Because of this fact, $\mathrm{N}$ fertilizers are often recommended in order to obtain profitable crop yields. Inasmuch as beans are legumes, the application of $\mathrm{N}$ fertilizers is sometimes questioned because of the general belief that legumes can fix enough $\mathrm{N}$ to supply plant requirements. Edge, et al. (7), working in Malawi during 1972 and 1973, found that seed yields increased significantly in both years with increasing rates of $\mathrm{N}$ from $2150 \mathrm{~kg} / \mathrm{ha}$ in the no- $\mathrm{N}$ plots to 3779 in the $200 \mathrm{~kg} / \mathrm{ha}-\mathrm{N}$ plots. Other investigators also observed a response in yields to $\mathrm{N}$ levels under various conditions $(1,3,12)$. Jansen and Vitosh (10) found that symbiotic $\mathrm{N}$ fixation by the Rhizobiumlegume association of field beans (dark red kidney) does not provide sufficient $\mathrm{N}$ for optimum yields under Michigan growing conditions. An average of nearly $45 \mathrm{~kg} / \mathrm{ha}$ of $\mathrm{N}$ is applied to this crop each year in that area.

${ }^{1}$ Manuscript submitted to Editorial Board February 22, 1977.

2 Joint contribution from the Department of Agronomy, Cornell University, Ithaca, N.Y., and the Agricultural Experiment Station, University of Puerto Rico, Mayagüez Campus, Río Piedras, P.R. This study was part of the investigations supported by the USAID under research contract ta-c-1104 entitled: "Soil fertility in the humid tropics".

${ }^{3}$ Former Professor and Soil Scientist, Agricultural Experiment Station, University of Puerto Rico, now Consultant, Cornell University; Associate Agronomist and Research Assistant, respectively, Agricultural Experiment Station, Mayagüez Campus, University of Puerto Rico, Río Piedras, P.R. 
Field beans are important sources of protein in the diet, probably the most important single source of protein in some less-developed countries of the tropical regions. In some places, such as Puerto Rico, beans with rice are consumed twice daily. However, the bulk of the beans consumed is imported at an annual cost of almost \$14 million. ${ }^{4}$ Native white beans are a favorite in many homes, but production levels have been decreasing throughout the years.

This paper reports on the first experiment of a series to evaluate the possibilities of commercial field bean production in the acid Oxisols of northern Puerto Rico. The study attempts to evaluate production levels of native white bean under various inputs of fertilizer $N$.

\section{MATERIALS AND METHODS}

The experiment was conducted on a Coto soil, a Tropeptic Haplorthox, clayey, kaolinitic, isohyperthermic, in northwestern Puerto Rico (11). It has a $\mathrm{pH}$ of 5 , a cation exchange capacity of about 13 meq, and $25 \%$ calcium saturation. It is high in $\mathrm{Mn}$ and low in P. Mean annual rainfall is about $1658 \mathrm{~mm}$. Evaporation from a Class A pan is approximately $6 \mathrm{~mm} /$ day during the summer and $4 \mathrm{~mm} /$ day during the winter. The mean annual maximum temperature is $29.4^{\circ} \mathrm{C}$ while the mean minimum temperature is $18.9^{\circ} \mathrm{C}$. Solar radiation ranges from an average of 300 langleys/day in the winter to 600 in the summer. The elevation is about $122 \mathrm{~m}$ above sea level.

The experiment followed a balanced lattice design with six treatments and four replications. Plots were $3.5 \mathrm{~m} \times 3.5 \mathrm{~m}$ with five rows per plot. Rows were $61 \mathrm{~cm}$ apart and plants $7.6 \mathrm{~cm}$ apart. The experiment was planted on November 20, 1975 using the native, determinate, selected white bean variety Bonita, which Island consumers prefer. Each plot received at planting time a blanket application of fertilizer equivalent to $112 \mathrm{~kg} / \mathrm{ha}$ of $\mathrm{P}_{2} \mathrm{O}_{5}$ as triple superphosphate, $112 \mathrm{~kg} / \mathrm{ha}$ of $\mathrm{K}_{2} \mathrm{O}$ as potassium sulfate, $56 \mathrm{~kg} / \mathrm{ha}$ of $\mathrm{Mg}$ as sulfate, and $3.41 \mathrm{~kg} / \mathrm{ha} \mathrm{Zn}$ as sulfate. Dacthal, ", at the rate of $13.5 \mathrm{~kg} / \mathrm{ha}$ was used as a preemergent herbicide. Chlordane E8, at the rate of $946 \mathrm{~cm}^{3} / 378$ liters of water was used to control soil insects; Diazinon AG-500 at the rate of $473 \mathrm{~cm}^{3} / 189$ liters of water was used as necessary for the control of leaf eating insects.

Treatment differentials were imposed at planting time, as follows: 0 ,

${ }^{4}$ Pringle, G., Personal communication, November 1976.

5 Trade names are used in this publication solely for the purpose of providing specific information. Mention of a trade name does not constitute a guarantee or warranty of equipment or materials by the Agricultural Experiment Station of the University of Puerto Rico or an endorsement over other equipment or materials not mentioned. 
$20,40,80,160$, and $320 \mathrm{~kg} / \mathrm{ha}$ of $\mathrm{N}$ as ammonium sulfate, broadcast and then incorporated into the topsoil.

The beans were harvested on February 9, 1976 at 81 days of age. Data were taken on bean yield, weight of 10 plants, number and weight of pods/10 plants, number of beans/10 pods, weight of 100 beans, plant height, and plant canopy diameter. Weights were adjusted on a dry basis. All data were statistically analyzed. The Capó fertilizeryield equation (5) was fitted to the dry bean yield data. Analyses of variance were applied to the rest of the data.

\section{RESULTS AND DISCUSSION}

Data on adjusted mean yields per hectare are given in the following tabulation:

$\begin{array}{cc}N, \mathrm{~kg} / \mathrm{ha} & \text { Marketable yields, } \mathrm{kg} / \mathrm{ha} \\ 0 & 1313 \\ 20 & 1342 \\ 40 & 1367 \\ 80 & 1412 \\ 160 & 1460 \\ 320 & 1369\end{array}$

The highest yields were obtained from application of $160 \mathrm{~kg} / \mathrm{ha}$ of $\mathrm{N}$ as ammonium sulfate.

The Capó fertilizer-yield equation (5) was applied to the mean yield data. The equation is as follows:

$$
Y=\frac{A}{1+B(X-C)^{2}}
$$

where,

$Y=$ yield in $\mathrm{kg} / \mathrm{ha}$

$A=1461.21$; the maximum yield obtainable in the given field by fertilizing with ammonium sulfate

$B=3.45 \times 10^{-6}$, is another parameter related to this equation;

$C=180.44$; the fertilizer application required for maximum crop yield under prevalent conditions, and

$X=$ amount of $\mathrm{N}$ applied in $\mathrm{kg} / \mathrm{ha}$

The curvilinear equation developed is useful in predicting to some extent dry bean yields in terms of the $\mathrm{N}$ fertilizer applied within the range used in the present experiment. Although the equation indicated that not more than $180 \mathrm{~kg} / \mathrm{ha}$ of $\mathrm{N}$ are needed to complement native soil $\mathrm{N}$ to obtain maximum bean yields, an application of only $80 \mathrm{~kg} / \mathrm{ha}$ produced $96.7 \%$ of the estimated maximum yield.

A field-wide average of over $1375 \mathrm{~kg} / \mathrm{ha}$ was obtained, which is considered fairly good under the conditions prevailing at the experimen- 
tal site. González-Ríos and Riollano (9), in extensive field testing during 1944-45 at Isabela, failed to reach yields of this magnitude of selected dry native white beans. When higher yielding cultivars are obtained and a complete technological package of practices developed, yields might be substantially increased. Under local conditions yields of this magnitude are quite satisfactory.

Data on agronomic characters are given in table 1 . Weight of ten plants was significantly higher in the $160 \mathrm{~kg} / \mathrm{ha} \mathrm{N}$ treatment than in the 0 and $40 \mathrm{~N}$ levels. Again, the number and the weight of pods/10 plants were significantly higher in the $160 \mathrm{~N}$ level than in the 0 and 40 $\mathrm{N}$ levels. Number of seeds/pods was significantly lower in the $0-\mathrm{N}$ treatment as compared to the $80 \mathrm{~kg} / \mathrm{ha} \mathrm{N}$ treatment.

As shown in table 1 , plants from the $160 \mathrm{~kg} / \mathrm{ha} \mathrm{N}$ level were significantly taller than those from the no- and $20 \mathrm{~kg} / \mathrm{ha}-\mathrm{N}$ levels. No significant differences in plant canopy diameter were found which

TABLE 1. - Agronomic characteristics of Bonita, a native white field bean, grown at six $N$ levels on an Oxisol

\begin{tabular}{cccccccc}
\hline N levels & $\begin{array}{c}\text { Weight of } 10 \\
\text { plants }\end{array}$ & $\begin{array}{c}\text { Pods/10 } \\
\text { plants }\end{array}$ & $\begin{array}{c}\text { Weight of } \\
\text { pods/10 } \\
\text { plants }\end{array}$ & $\begin{array}{c}\text { Seeds/10 } \\
\text { pods }\end{array}$ & $\begin{array}{c}\text { Weight of } \\
\text { 100 seeds }\end{array}$ & Plant height & $\begin{array}{c}\text { Canopy } \\
\text { diameter }\end{array}$ \\
\hline$K g / h a$ & $G$ & No & $G$ & No & $G$ & $C m$ & $C m$ \\
0 & $114 \mathrm{~d}^{\prime}$ & $73 \mathrm{c}$ & $99 \mathrm{~b}$ & $44 \mathrm{~b}$ & $10.6 \mathrm{a}$ & $40 \mathrm{~b}$ & $47 \mathrm{a}$ \\
20 & $224 \mathrm{ac}$ & $135 \mathrm{a}$ & $181 \mathrm{ac}$ & $55 \mathrm{ab}$ & $10.3 \mathrm{a}$ & $41 \mathrm{~b}$ & $48 \mathrm{a}$ \\
40 & $175 \mathrm{~cd}$ & $98 \mathrm{~b}$ & $144 \mathrm{bc}$ & $53 \mathrm{ab}$ & $9.8 \mathrm{a}$ & $42 \mathrm{ab}$ & $49 \mathrm{a}$ \\
80 & $244 \mathrm{ab}$ & $122 \mathrm{ab}$ & $198 \mathrm{ac}$ & $60 \mathrm{a}$ & $10.2 \mathrm{a}$ & $42 \mathrm{ab}$ & $50 \mathrm{a}$ \\
160 & $285 \mathrm{a}$ & $155 \mathrm{a}$ & $218 \mathrm{a}$ & $59 \mathrm{ab}$ & $10.0 \mathrm{a}$ & $46 \mathrm{a}$ & $50 \mathrm{a}$ \\
320 & $246 \mathrm{ac}$ & $130 \mathrm{ab}$ & $193 \mathrm{ac}$ & $57 \mathrm{ab}$ & $11.2 \mathrm{a}$ & $45 \mathrm{ab}$ & $52 \mathrm{a}$ \\
\hline
\end{tabular}

' Values in a column followed by one or more letters in common do not differ significantly at the 5\% level, using Duncan's multiple range test.

could be attributable to treatments. Plants ranged from 46 to $52 \mathrm{~cm}$ in canopy diameter.

In general, plants were free of the attack of the leaf hopper (Empoasca fabalis) and other insects, as well as of disease. This may be attributed to the late November planting, permitting the crop to enjoy the relatively short, cool, dry days of the winter season. The excellent drainage of the Coto soil was also probably an important factor in keeping the plants free of root rot and other diseases.

From the results of field trials designed to evaluate symbiotic $\mathrm{N}$ fixation by $P$. vulgaris conducted in Kenya, De Souza (6) has shown that this legume can fix enough $N$ to meet its nutritional requirements. The possible contribution of Rhyzobium fixation on this soil remains undetermined as yet. This aspect should be further explored on tropical soils, particularly as related to mineral nutrition. It appears that 
mineral nutrition has an important role in determining the quantity of $\mathrm{N}$ fixed by a legume, because the $\mathrm{N}$ fixation process depends on energyyielding metabolism, electron transport systems, and substrates from the host plant $(2,4,8)$. Furthermore, some nutrients are specifically required for $\mathrm{N}$ fixation and are needed when the legume is in symbiosis.

\section{RESUMEN}

Las habichuelas, Phaseolus vulgaris, se consideran leguminosas pobres in fijación de N. Por esto generalmente se recomienda aplicarles abonos completos. Por lo tanto, se estudió la demanda de $\mathrm{N}$ de una cosecha de habichuelas secas. El experimento se hizo en un suelo Coto, un Tropeptic Haplorthox, de la zona noroeste de Puerto Rico. Se sembraron habichuelas blancas del país, variedad Selección Bonita, la cual tiene gran demanda en el mercado aunque comercialmente se siembran sólo en pequeña escala. Se estudiaron seis niveles de N: 0, 20, 40, 80, 160 y $320 \mathrm{~kg}$./ha. Se aplicó la ecuación abonorendimiento desarrollada por Capó, la que aparentemente es útil para predecir los rendimientos de habichuelas secas en términos del $\mathrm{N}$ aplicado como abono. Aparentemente, $180 \mathrm{~kg}$./ha. de $\mathrm{N}$ bastan para complementar el $\mathrm{N}$ del suelo y lograr rendimientos máximos de habichuelas secas. El $96.7 \%$ del rendimiento máximo se obtiene con $80 \mathrm{~kg} . /$ ha. de N. Se midieron diferencias significativas en algunos componentes del rendimiento. El peso, el número de vainas y el peso de las vainas de 10 plantas fueron significativamente mayores acuando recibieron $\mathrm{N}$ a razón de $160 \mathrm{~kg}$./ ha. que cuando no recibieron $\mathrm{N}$ o recibieron sólo $40 \mathrm{~kg}$./ha. El número de semillas por vaina fue significativamente menor en plantas que no recibieron $\mathrm{N}$ que en las que recibieron 80 $\mathrm{kg}$./ha. de N. No hubo diferencias significativas en el ancho del follaje de las plantas, pero las que recibieron $160 \mathrm{~kg}$./ha. de $\mathrm{N}$ fueron más altas que las que no recibieron $\mathrm{N} 0$ que sólo recibieron $20 \mathrm{~kg}$. $/ \mathrm{ha}$.

\section{LITERATURE CITED}

L. Bains, K. S., Effects of applied nutrients on soil fertility, chemical composition, and yield of field beans, Indiana J. Agron. 12(2): 200-6, 1967.

2. Bergersen, F. J., The central reactions of nitrogen fixation, Plant Soil, Special Vol. 1971: 511-24, 1971.

3. Burke, D. W., and Nelson, C. E., Response of field beans to nitrogen fertilization of Fusarium-infested and noninfested land, Wash. Agric. Exp. Sta. Bull. 687, 1967.

4. Burton, K., Allen, O. N., and Berger, K. C., Effect of certain mineral nutrients on growth and nitrogen fixation of inoculated bean plants, Phaseolus vulgaris, L., J. Agric. Food Chem. 9: 187-90, 1961.

5. Capó, B. G., A new fertilizer-yield equation, Proc. XII Congr. Int. Soc. Sugarcane Tech. pp 380-7, 1965.

6. De Souza, D. I. A., Legume nodulation and nitrogen fixation studies in Kenya, E. Afr. Agric. For. J. 34: 299-305, 1969.

7. Edge, O. T., Mughogho, L. K., and Ayonoadu, V. W. V., Responses of dry beans to varying nitrogen levels, Agron. J. 67(2): 251-5, 1975.

8. Fred, E. B., Baldwin, I. L., and McCoy, E., Root nodule bacteria and leguminous plants, Univ. Wis. Press, Madison, Wis., 1932.

9. González-Ríos, P., and Riollano, A., El majoramiento de la habichuela blanca del país (Phaseolus vulgaris) por medio de la selección, Agric. Exp. Sta. Univ. P.R. Bol. 94, 21 pp, 1951.

10. Jansen, K. A., and Vitosh, M. C., Effect of lime, sulfur and molybdenum on $\mathrm{N}_{2}$ fixation and yield of dark red kidney beans, Agron. J. 66(6): 736-40, 1974.

11. Lugo-López, M. A., and Rivera, L. H., Taxonomic classification of the soils of Puerto Rico, 1975, Agric. Exp. Sta. Univ. P.R. Bull. 245, 32 pp, 1976.

12. Spurling, A. T., Field trials with Canadian Wonder beans in Malawi, Exp. Agric. 9(2): $97-105,1973$. 